\title{
Anti-CD20 B Cell Treatment for Relapsing Multiple Sclerosis
}

\author{
Charles A. Roach and Anne H. Cross* \\ Department of Neurology, Washington University School of Medicine, St. Louis, MO, United States
}

Several clinical trials have demonstrated the efficacy of lytic therapies targeting B cells in the treatment of relapsing multiple sclerosis (MS). More modest efficacy has been noted in the primary progressive subtype of MS. Clinical success has increased interest in the role of B cells in the pathogenesis of MS and in ways to potentially improve upon current B cell therapies. In this mini review, we will critically review previous and ongoing clinical trials of anti-CD20 monoclonal antibodies in MS, including rituximab, ocrelizumab, ofatumumab, and ublituximab. Side effects and adverse event profiles will be discussed. Studies examining the proposed mechanisms of action of B cell depleting therapies will also be reviewed.

\section{OPEN ACCESS}

Edited by:

Francesca Gilli,

Dartmouth College, United States

Reviewed by:

David Baker,

Queen Mary University of London,

United Kingdom

Alice Laroni

University of Genoa, Italy

*Correspondence:

Anne H. Cross

crossa@wustl.edu

Specialty section:

This article was submitted to

Multiple Sclerosis and

Neuroimmunology,

a section of the journal

Frontiers in Neurology

Received: 17 August 2020

Accepted: 28 December 2020

Published: 22 January 2021

Citation:

Roach CA and Cross AH (2021)

Anti-CD20 B Cell Treatment for

Relapsing Multiple Sclerosis.

Front. Neurol. 11:595547.

doi: 10.3389/fneur.2020.595547
Keywords: multiple sclerosis, anti-CD20 agent, rituximab, ofatumumab, ocrelizumab, ublituximab

\section{INTRODUCTION}

Four lytic monoclonal antibodies that target the CD20 molecule on B cells have now undergone clinical trials in relapsing multiple sclerosis (RMS). These successful trials showed B cell depletion to be an effective treatment for RMS, focusing scientific attention on the role of B cells in MS. Here we summarize trials using anti-CD20 therapies in RMS and discuss proposed mechanisms of action. Although rituximab (RTX) and ocrelizumab (OCR) have been studied in and OCR is approved for primary progressive MS (PPMS) $(1,2)$, due to word limitations PPMS studies will not be discussed.

\section{CLINICAL TRIALS OF B-CELL THERAPIES IN RELAPSING MULTIPLE SCLEROSIS}

\section{Rituximab}

Rituximab is a chimeric mouse-human monoclonal lytic antibody directed at $\operatorname{CD} 20(3,4)$. Two early phase clinical trials of B-cell depletion using RTX as a therapy in relapsing-remitting MS (RRMS) $(5,6)$ are summarized in Table 1A. An early phase 2 trial in 30 RMS patients with contrastenhanced lesions (CELs) on brain MRI used RTX at oncology dosing ( $375 \mathrm{mg} / \mathrm{m}^{2}$ weekly, 4 doses) as add-on to injectable disease modifying therapies (DMTs) (5). It showed $88 \%$ reduction of number of CELs on brain MRIs after RTX treatment $(p<0.0001)$.

The HERMES trial was the first double-blind, placebo-controlled trial of RTX in RMS, and demonstrated a significant reduction in CELs $(p<0.001)$ along with an almost $50 \%$ reduction in ARR at 48 weeks $(p=0.04)$ vs. placebo (6). CELs remained near zero at 48 weeks, despite no further treatment. These and concurrent observational studies (10) led to increased interest in targeting B cell therapies for the treatment of MS.

As a mouse-human chimeric $\mathrm{mAb}$, development of anti-drug neutralizing $\mathrm{mAbs}$ is of concern. RTX is approved for chronic use in several diseases, such as rheumatoid arthritis and Wegener's 
granulomatosis (but not for MS in the United States). Depending on the disease, the duration of exposure to RTX and the assay methodology, anti-RTX Abs (not all of which were shown to be neutralizing) have been reported in 11 to $>50 \%$ of people taking RTX chronically (11).

\section{Ocrelizumab}

Ocrelizumab (OCR) is a fully humanized lytic mAb targeting CD20 (14). As a fully humanized mAb, it evokes less anti-drug antibody formation. A phase 2 randomized, double-blind trial compared $600 \mathrm{mg}$ OCR and 2,000 mg OCR delivered intravenously on days 1 and 15 with placebo and with IFN $\beta$ 1a 30 micrograms IM weekly 1:1:1:1 in 218 RRMS subjects (Table 1A) (14). The study showed $89 \%$ reduction in the total number of CELs at 24 weeks in the OCR $600 \mathrm{mg}$ group $(p<$ $0.0001)$ and $96 \%$ reduction in the $2,000 \mathrm{mg}$ group $(p<0.0001)$ vs. placebo. ARR at 24 weeks was 0.13 in the $600 \mathrm{mg}$ dose OCR group, significantly $<0.64$ for placebo and 0.36 for IFN $\beta$ - 1 a. ARR was also reduced in the $2,000 \mathrm{mg}$ dose OCR group compared to placebo but did not reach statistical significance compared to IFN $\beta-1$.

TABLE 1A | A summary of the phase 2 clinic trials of anti-CD20 therapies in RRMS.

\begin{tabular}{|c|c|c|c|c|c|c|c|c|c|}
\hline $\begin{array}{l}\text { Anti- } \\
\text { CD20 } \\
\text { mAb }\end{array}$ & $\begin{array}{l}\text { Primary } \\
\text { endpoint }\end{array}$ & $\begin{array}{l}\text { Intervention/ } \\
\text { control groups }\end{array}$ & $\begin{array}{l}\text { Patient number } \\
\text { (\% Female) }\end{array}$ & $\begin{array}{l}\text { Mean age } \pm \\
\text { Standard } \\
\text { deviation }\end{array}$ & $\begin{array}{l}\text { ARR } \\
\text { [relative } \\
\text { reduction] } \\
\text { (p-value) }\end{array}$ & $\begin{array}{l}\text { Disability } \\
\text { progression } \\
\text { (p-value) }\end{array}$ & $\begin{array}{l}\text { Mean new } \\
\text { CELs } \\
\text { (p-value) }\end{array}$ & $\begin{array}{l}\text { Mean new T2 } \\
\text { lesions } \\
\text { (p-value) }\end{array}$ & References \\
\hline \multirow[t]{2}{*}{$\begin{array}{l}\text { RTX } \\
\text { (HERMES } \\
\text { Trial) }\end{array}$} & \multirow{2}{*}{$\begin{array}{l}\text { Number of } \\
\text { CELs at } \\
\text { weeks } 12,16 \text {, } \\
20 \text {, and } 24\end{array}$} & RTX $1,000 \mathrm{mg}$ IV & 69 (52\%) & $39.6 \pm 8.7$ & $\begin{array}{l}0.20[50 \%] \\
(p=0.04)\end{array}$ & NR & $0.2(p<0.001)$ & NS & \multirow[t]{2}{*}{ (6) } \\
\hline & & Placebo & 35 (29\%) & $45.5 \pm 8.5$ & 0.40 & NR & 4.5 & NS & \\
\hline RTX & $\begin{array}{l}\text { Number of } \\
\text { CELs on } 3 \\
\text { pre-treatment } \\
\text { MRIs vs. } 3 \\
\text { post- } \\
\text { treatment } \\
\text { MRIs }\end{array}$ & $\begin{array}{l}\text { RTX } 375 \mathrm{mg} / \mathrm{m}^{2} \\
\text { weekly } \times 4 \\
\text { doses as add on } \\
\text { to IFN } \beta \text { or } \\
\text { glatiramer } \\
\text { acetate. }\end{array}$ & 30 (73.3\%) & $43.5(20-50)$ & 0.23 & NR & $\begin{array}{l}88 \% \text { reduction } \\
\text { post-treatment } \\
\text { vs. } \\
\text { pre-treatment }\end{array}$ & $N R$ & (5) \\
\hline \multirow[t]{4}{*}{ OCR } & \multirow{4}{*}{$\begin{array}{l}\text { Number of } \\
\text { CELs at } \\
\text { weeks 12, 16, } \\
20,24\end{array}$} & OCR $600 \mathrm{mg}$ & 55 (64\%) & $35.6 \pm 8.5$ & $\begin{array}{l}0.13[79 \%] \\
(p=0.0005)\end{array}$ & NR & $\begin{array}{l}0.8 \\
(p<0.0001)\end{array}$ & $\begin{array}{l}0.0 \\
(p<0.0001)\end{array}$ & \multirow[t]{4}{*}{ (7) } \\
\hline & & OCR 2,000 mg & 55 (69\%) & $38.5 \pm 8.7$ & $\begin{array}{l}0.17 \\
{[73 \%],} \\
(p=0.0014)\end{array}$ & NR & $\begin{array}{l}0.8 \\
(p<0.0001)\end{array}$ & $\begin{array}{l}0.0 \\
(p<0.0001)\end{array}$ & \\
\hline & & $\begin{array}{l}\text { IFN } \beta \text {-1a } 30 \\
\text { mcg/week IM }\end{array}$ & 54 (59\%) & $38.1 \pm 9.3$ & $\begin{array}{l}0.36[43 \%] \\
(p=0.07)\end{array}$ & NR & 7.2 & 1.8 & \\
\hline & & $\begin{array}{l}\text { Placebo } \\
\text { infusions days } 1 \\
\text { and } 15 \text {, received } \\
\text { OCR at } 24 \\
\text { weeks }\end{array}$ & $54(67 \%)$ & $38.0 \pm 8.8$ & 0.64 & NR & 6.6 & 1.4 & \\
\hline \multirow[t]{2}{*}{ OFA } & \multirow[t]{2}{*}{ Safety } & $\begin{array}{l}\text { OFA } 100,300 \text {, } \\
\text { or } 700 \mathrm{mg} \times 2 \\
\text { doses followed } \\
\text { by placebo }\end{array}$ & 26 (61.5\%) & $36.3 \pm 7.9$ & NS & NS & $\begin{array}{l}8-24 \text { weeks } \\
0.04 \\
(p<0.001) \\
24-48 \text { weeks } \\
0.12\end{array}$ & $\begin{array}{l}8-24 \text { weeks } \\
0.12 \\
(p<0.001) \\
24-48 \text { weeks } \\
0.12\end{array}$ & \multirow[t]{2}{*}{ (8) } \\
\hline & & $\begin{array}{l}\text { Placebo } \\
\text { followed by OFA } \\
100,300 \text {, or } \\
700 \mathrm{mg} \times 2 \\
\text { doses }\end{array}$ & 12 (50\%) & $36.0 \pm 9.1$ & NS & NS & $\begin{array}{l}\text { 8-24 weeks } \\
9.69 \\
24-48 \text { weeks } \\
0.09\end{array}$ & $\begin{array}{l}\text { 8-24 weeks } \\
10.67 \\
24-48 \text { weeks } \\
0.09\end{array}$ & \\
\hline \multirow[t]{2}{*}{ UTX } & \multirow[t]{2}{*}{$\begin{array}{l}\text { B cell } \\
\text { depletion }\end{array}$} & $\begin{array}{l}\text { Ublituximab } \\
150 \text { mg IV } \\
\text { followed by } 400 \\
\text { or } 600 \mathrm{mg} \text { at } \\
\text { weeks } 2 \text { and } 24\end{array}$ & $\begin{array}{l}36 \text { (reported in } \\
\text { subgroups only) }\end{array}$ & $\begin{array}{l}\text { Reported in } \\
\text { subgroups } \\
\text { only }\end{array}$ & 0.07 & $\begin{array}{l}12 \text { weeks } \\
7.0 \% \\
24 \\
\text { weeks } 17.0 \%\end{array}$ & 0.00 & $\begin{array}{l}24-48 \text { weeks } \\
0.2\end{array}$ & \multirow[t]{2}{*}{ (9) } \\
\hline & & Placebo & $12(\mathrm{NR})$ & NR & NR & NR & NR & NR & \\
\hline
\end{tabular}

ARR, annualized relapse rate; CEL, contrast enhancing lesions; mAb, monoclonal Antibody; NS, not significant; NR, not reported; OCR, Ocrelizumab; OFA, Ofatumumab; RRMS, Relapsing Remitting MS; UTX, Ublituximab. 
TABLE 1B | A summary of the phase 3 clinical trials of anti-CD20 therapies in RRMS.

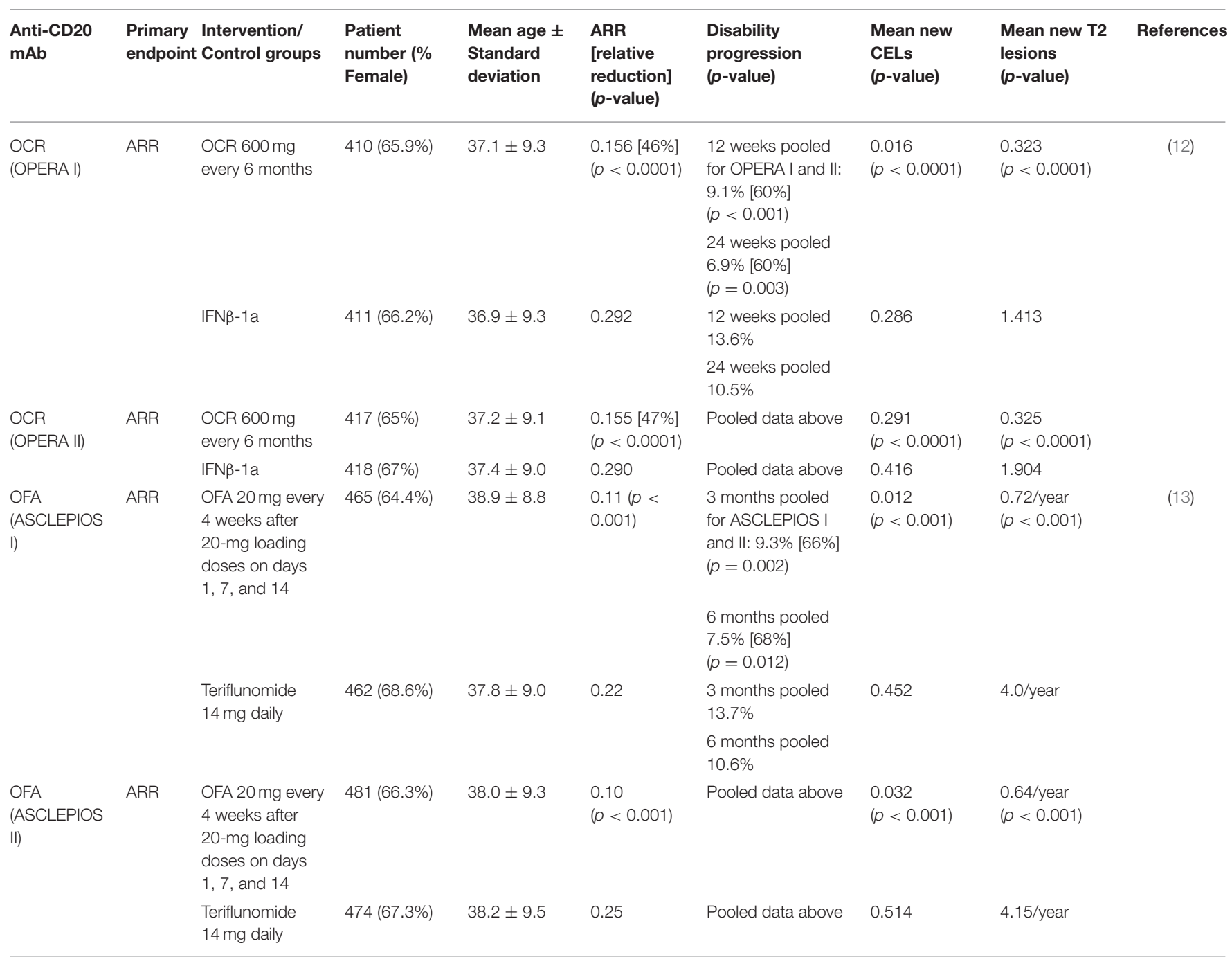

ARR, annualized relapse rate; CEL, contrast enhancing lesions; mAb, monoclonal Antibody; NS, not significant; NR, not reported; OCR, Ocrelizumab; OFA, Ofatumumab; RRMS, Relapsing Remitting MS; UTX, Ublituximab.

Two identically designed phase 3 trials (OPERA I and II) compared OCR with IFN $\beta$-1a in RRMS (12). These multicenter, double-blind, double-dummy, parallel-group trials enrolled 1,656 RRMS patients (OPERA I 821; OPERA II 835) who were randomized 1:1 to receive OCR $600 \mathrm{mg}$ every 24 weeks or IFN $\beta$ 1a 44 micrograms subcutaneously injected three times per week over 96 weeks. Patients were between 18 and 55 years of age, with EDSS score $\leq 5.5$, and had at least two documented clinical attacks within 2 years, or 1 within 1 year prior to screening. The primary endpoint, ARR, was reduced relative to IFN $\beta$-1a by 46 and $47 \%$, CELs were reduced by 94 and $95 \%$, the number of new and/or enlarging T2 lesions was reduced by 77 and $83 \%$, and rate of brain volume loss was reduce by 22.8 and $14.9 \%$ in OPERA I and OPERA II, respectively. In pre-specified pooled analyses, the percentage of subjects with 3 months confirmed disability worsening $(\mathrm{CDW})$ and 6 -months $\mathrm{CDW}$ was $40 \%$ lower in the OCR groups compared with IFN $\beta$-1a (Table 1B).

\section{Ofatumumab}

Ofatumumab (OFA) is fully human mAb targeting CD20expressing cells (15). An early small phase 2, placebo-controlled, double-blind trial demonstrated no safety concerns in 38 RRMS subjects OFA or placebo 2 weeks apart (Table 1A) (8). This study was followed by a larger, phase 2 , multicenter, doubleblind study of OFA (17) that enrolled 232 RRMS subjects randomized to receive subcutaneous OFA 3,30 , or $60 \mathrm{mg}$ every 12 weeks, OFA $60 \mathrm{mg}$ every 4 weeks, or placebo every 12 weeks or every 4 weeks for 24 weeks. After the 12-weeks placebocontrolled period, the placebo group received a single $3 \mathrm{mg}$ OFA dose while the remaining subjects continued their original dose of OFA. At 12 weeks, mean cumulative new CELs was reduced $65 \%$ for all OFA groups compared with placebo $(p<$ 0.001). Post-hoc analysis excluding weeks $1-4$ estimated $a \geq 90 \%$ reduction in CELs at 12 weeks for all groups that received $\geq 30 \mathrm{mg}$ OFA. 
Two identically designed multicenter, double-blind, double-dummy, parallel-group phase 3 trials compared $20 \mathrm{mg}$ subcutaneous OFA every 4 weeks to $14 \mathrm{mg}$ oral teriflunomide daily, randomized 1:1 (13). The trials enrolled 927 and 955 subjects, respectively. Subjects enrolled were mostly RRMS, but a small percentage (5.9\% in ASCLEPIOS I and 5.6\% in ASCLEPIOS II) had active secondary progressive MS (SPMS). Inclusion required at least 2 documented clinical attacks within 2 years or 1 within 1 year of screening, or a CEL on MRI in the year before randomization. EDSS scores at baseline were $\leq 5.5$. Both studies met their primary endpoint with similar and significant relative reductions in ARR in the OFA arms. ARR for the OFA arms were reduced by over $50 \%$ relative to the teriflunomide arms ( 0.11 vs. 0.22 and 0.10 vs. 0.25 in ASCLEPIOS I and II, respectively). Significant (>30\%) reductions in CDW relative to teriflunomide were seen in pooled 3 and 6-months CDW analyses (10.9 vs. $15.0 \%$ and 8.1 vs. $12.0 \%$, respectively). Six-months sustained disability improvement favored the OFA arm in both trials but did not reach statistical significance. Significant reductions in mean CELs per scan ( 0.01 vs. 0.45 , and 0.03 vs. 0.51 in ASCLEPIOS I and II, respectively) and new or enlarging T2 lesions per year (0.72 vs. 4.00 , and 0.64 vs. 4.15 , respectively) were seen in the OFA vs. teriflunomide groups. Serum neurofilament light chain concentrations were reduced in the OFA arm relative to teriflunomide arm by $7 \%$ at month $3,27 \%$ at month 12 , and $23 \%$ at month 24 in ASCLEPIOS I and by $11 \%$ at month $3,26 \%$ at month 12 , and $24 \%$ at month 24 in ASCLEPIOS II (Table 1B).

\section{Ublituximab}

Ublituximab (UTX) is a chimeric mAb targeting CD20 that has been glycoengineered to remove sugar molecules, resulting in enhanced lytic potency (18) (Table 2). In a phase 2, placebocontrolled trial of UTX, 48 RRMS subjects were randomized 3:1 to receive UTX IV or placebo on day 1, day 15, and week 24 (9). No CELs were seen at weeks 24 and 48 , and a $10.6 \%$ reduction in T2 lesion volume was seen in the UTX group vs. placebo. Further studies of this drug are ongoing. As a chimeric mAb, the potential development of anti-UTX Abs will need to be monitored.

\section{SAFETY CONSIDERATIONS}

\section{Infusion Reactions}

Infusion reactions were the most common adverse events in the OCR and RTX phase 3 trials. These were mostly mild to moderate in severity and decreased in rate and severity with subsequent dosing. There were no fatal or life-threatening reactions in the phase 3 trials. Longer-term safety event reporting data suggest that infusion related reactions occur at similar rates in MS patients treated with RTX and OCR at 4.82 and $4.76 \%$, respectively (19). Injection reactions with subcutaneous OFA occurred at 16.1 and $24.1 \%$ in the ASCLEPIOS I and II trials, respectively and were largely confined to the first dose.

\section{Infections Including Progressive Multifocal Leukoencephalopathy (PML) and COVID-19}

The most common minor infections seen in the phase 3 trials of RTX, OCR, and OFA were upper respiratory infections, nasopharyngitis, and urinary tract infections (UTIs). These occurred at similar rates in the anti-CD20 groups of these trials. Recent real-world safety reporting data showed nearly a 2-fold higher rate of minor infections in OCR compared to RTX with significantly higher rates of UTIs, nasopharyngitis, and oral herpes (19).

As of end of January 2020, nine cases of definite PML according to AAN criteria have been reported in MS patients receiving OCR (20). Seven of these cases were in antiJCV antibody positive patients who had previously received natalizumab; one case occurred in a patient previously treated with fingolimod. One reported case of PML occurred in a patient treated with OCR that had not received prior DMTs, but this was confounded by older patient age (78 years) and low absolute lymphocyte counts prior to OCR treatment.

A potential risk of anti-CD20 therapies in people with MS infected with SARS-CoV-2 has been reported. A retrospective study of $784 \mathrm{MS}$ patients with SARS-CoV-2 infection conducted by the Italian MS and COVID-19 registry found increased risk of severe COVID-19 in people treated with OCR or RTX with an odds ratio of 2.59 ( $p=0.002$ ) (21). A multi-center retrospective French study with only 347 total patients did not find an association of severe COVID-19 with anti-CD20 therapies (22). The North American COViMS Registry has reported $858 \mathrm{MS}$ patients with SARS-CoV-2 infection (23). Multivariable logistic regression analysis demonstrated an OR of $2.31(p<0.002)$ for those on anti-CD20 to have higher chance of death, ICU or hospitalization compared with those on other DMTs. None of these early reports have true denominators. Research in this area is ongoing; COViMS Registry and several other worldwide efforts continue to accrue data.

\section{Malignancy}

Fifteen malignancies were observed over the 96-weeks study periods in patients randomized to OCR compared to 4 in the IFN $\beta$-1a or placebo groups in the phase 3 trials in RRMS and PPMS. The latest OCR package insert (dated May 2020) states that "an increased risk of malignancy, including breast cancer, may exist with OCREVUS." We recommend that all patients taking anti-CD20 mAbs closely adhere to standard cancer screening guidelines, including periodic skin checks for skin cancers.

\section{MECHANISM OF ACTION OF ANTI-CD20 MONOCLONAL ANTIBODIES IN MULTIPLE SCLEROSIS}

The most consistent laboratory abnormality found in MS patients is increased intrathecal production of antibodies (Abs), which is most sensitively detected as cerebrospinal fluid (CSF)-restricted oligoclonal bands (OCB). CSF-restricted OCBs are present in 
TABLE 2 | A summary of anti-CD20 antibody type, target, and mechanisms of lysing B lymphocytes.

\begin{tabular}{|c|c|c|c|}
\hline mAb & Antibody type and target & Mechanism of action & References \\
\hline RTX & $\begin{array}{l}\text { Mouse/human chimeric lgG1 mAb that targets } \\
\text { CD20 }\end{array}$ & $\begin{array}{l}\text { Lyses B cells by direct signaling of apoptosis, } \\
\text { complement activation, and ADCC }\end{array}$ & $(3,4)$ \\
\hline OCR & Humanized lgG1 mAb that targets CD20 & $\begin{array}{l}\text { Lyses B cells by ADCC and complement } \\
\text { mediated lysis }\end{array}$ & $(14)$ \\
\hline OFA & Fully human IgG1 mAb that targets CD20 & Lyses B cells by CDC and ADCC & $(15)$ \\
\hline UTX & $\begin{array}{l}\text { Mouse/human chimeric lgG1 mAb } \\
\text { glycoengineered for high affinity for Fc } \gamma \text { RIlla }\end{array}$ & $\begin{array}{l}\text { Enhanced lyses of B cells via ADCC compared to } \\
\text { RTX } \\
\text { Similar effects on apoptosis and CDC compared } \\
\text { to RTX }\end{array}$ & $(16)$ \\
\hline
\end{tabular}

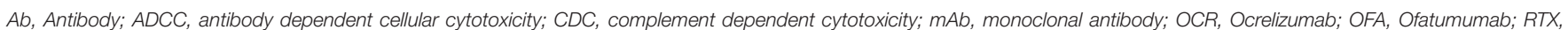
Rituximab; UTX, Ublituximab.

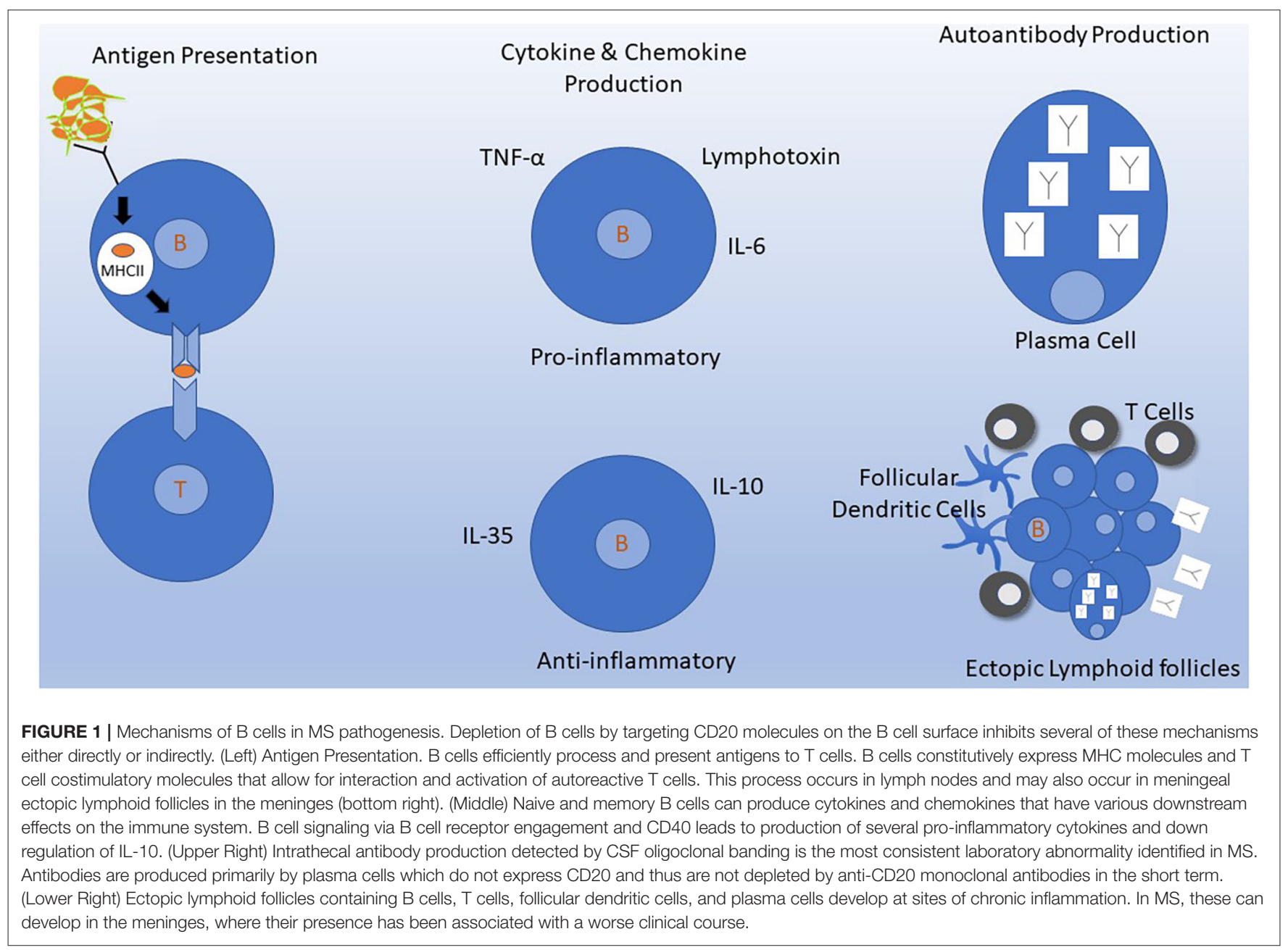

more than $90 \%$ of persons with definite MS (24). Elevated levels of CSF IgG and IgM, and number of OCBs have been correlated with worse MS prognosis $(25,26)$. This indirectly implicates B lymphocytes, as B cells produce Abs. However, plasma cells (which differentiate from B cells but do not express CD20) are the long-lived cells that produce most Abs.

Some insights into the mechanisms of action of $\mathrm{B}$ cell depletion with anti-CD20 mAb derived from the Phase 2 study we performed using oncologic doses of RTX $\left(375 \mathrm{mg} / \mathrm{m}^{2}\right.$ weekly $\times 4$ weeks). In this MRI-blinded open-label study (5), 26 of the 30 subjects underwent CSF and blood collection before and 6 months after RTX treatment. B cells declined in the CSF after RTX treatment in 20 of the 26 subjects $(p<0.0001$ by Wilcoxon matched pairs test). In the remaining six subjects, B cells were undetectable in CSF prior to or after RTX. CSF Abs as measured by IgG index, IgG concentration, and oligoclonal band number 
did not decline 6 months post-RTX (27). Because the major producers of $\mathrm{Ab}$ are plasma cells that do not express CD20, this was not surprising. Given the rapidity of the beneficial effects of anti-CD20 mAbs in RRMS, these studies suggested that reduced $\mathrm{Ab}$ levels are unlikely to be critical for the mechanism of action of anti-CD20 mAb therapies.

However, B cells have other functions aside from their role in Ab production (Figure 1). B cells comprise several subtypes, such as naive and memory $B$ cells, and including $B$ cells that produce proinflammatory (e.g., IL-6), or anti-inflammatory (e.g., IL-10) cytokines (28). Memory B cells are strongly implicated in the underlying pathophysiology of MS $(29,30)$. For this reason, studies to test the possibility of tailoring anti-CD20 treatments to target continued absence of circulating memory $\mathrm{B}$ cells are being pursued (31). Bar-Or and colleagues showed that B cell signaling via the combination of $B$ cell receptor engagement and CD40 leads to production of several pro-inflammatory cytokines (e.g., lymphotoxin and tumor necrosis alpha), while reducing B cell production of IL-10 (32). Two chemokines, CXCL13 and CCL19, were significantly decreased $(P=0.002$, $P=0.03$, respectively) in post-RTX CSF (27). Lysis of B cells using anti-CD20 eliminates their production of cytokines and chemokines and may contribute to the mechanism of action of anti-CD20 treatments.

$\mathrm{T}$ cells were also reduced in the CSF of $81 \%$ of subjects 6 months after RTX treatment $(27,33,34)$. The mean reduction of CSF B cells was $95 \%$ and of CSF $\mathrm{T}$ cells was $55 \%$. T cells were reduced in the CSF to a larger degree than the $12 \%$ reduction observed in blood, suggesting reduced $\mathrm{T}$ cell trafficking into the CNS. Activated T cells express CXCR5, the receptor for the chemoattractant factor CXCL13. CXCL13 is increased in CSF during several CNS inflammatory conditions, including MS (35) and CXCL13 was reduced 6 months postRTX (27). Reduced trafficking of T cells into the CSF appears to be an indirect consequence of $\mathrm{B}$ cell elimination, especially since B cells themselves do not produce CXCL13 (36). A better understanding of the manifold effects of anti-CD20 $\mathrm{mAb}$ therapy in MS is expected from a multicenter longitudinal study that is underway (NCT02688985).

B cells are constitutively able to process and present antigen to $\mathrm{T}$ cells, and they are extraordinarily efficient at this when presenting their own cognate antigen to $\mathrm{T}$ cells recognizing the same antigen $(37,38)$. B cells that target myelin recognize it via surface $B$ cell receptors, which enables efficient antigen capture of a self-antigen that is at low concentration. As B cells constitutively express MHC-I and MHC-II and the T cell costimulatory molecules CD86 and CD80, they are ready to process and present antigens to pathogenic autoreactive $\mathrm{T}$ cells (39). A process by which $\mathrm{B}$ cells that capture low concentration myelin antigens and then serve as antigenpresenting cells (APCs) to activate myelin-reactive $\mathrm{T}$ cells is postulated to be a trigger of MS activity. The interaction of $\mathrm{T}$ with $\mathrm{B}$ cells further cross-activates the $\mathrm{B}$ cells. Several groups have reported evidence that this process can occur in deep cervical lymph nodes $(40,41)$. In established MS, the process may occur in meningeal ectopic lymphoid-like structures (42).
Yet another mechanism through which anti-CD20 mAbs may act is the elimination of CD20-expressing T cells. A small proportion of circulating $\mathrm{T}$ cells express surface $\mathrm{CD} 20$; these cells are eliminated by anti-CD20 treatments. $\mathrm{CD} 20^{+} \mathrm{T}$ cells comprise only $3-5 \%$ of circulating $\mathrm{T}$ cells of healthy persons (43), but comprise a slightly higher proportion (up to 10\%) in MS patients $(44,45) . \mathrm{CD}^{+}$and $\mathrm{CD} 8^{+} \mathrm{CD} 20^{+} \mathrm{T}$ cells produce proinflammatory cytokines, such as interferon gamma, TNF-alpha and GM-CSF, which could contribute to MS pathogenesis (45). In MS, CSF T cells are enriched for those expressing CD20 ${ }^{+}$, but are still $<50 \%$ of CSF T cells (45) suggesting that the CSF $\mathrm{T}$ cell reduction observed after RTX treatment cannot be fully explained by their lysis by anti-CD20 $\mathrm{mAb}$.

An early report using the lytic anti-CD19 mAb, inebilizumab, in MS showed benefit on MRI activity to a similar strong degree as seen with anti-CD20 therapies (46). This study may provide insights, as the CD19 molecule is expressed on B cells but not on T cells. Results using inebilizumab hinted that lysis of $\mathrm{CD} 20^{+}$ $\mathrm{T}$ cells is not responsible for all beneficial effects of anti-CD20 $\mathrm{mAb}$ treatments.

\section{OTHER EMERGING B CELL THERAPIES IN MS}

Success in therapeutics with targeting CD20 on B cells has raised interest in other mechanisms to target $\mathrm{B}$ cells, but the results have not always been as expected. Early on, the drug atacicept was tried in two studies, one in optic neuritis patients in hope of preventing MS development and the second in MS patients in a phase 2 trial. Atacicept is a human recombinant fusion protein that comprises the binding portion of a receptor for both B-Lymphocyte Stimulator (B-LyS) and A PRoliferationInducing Ligand (APRIL), two important factors supporting B cell maturation and survival. Unexpectedly atacicept led to more attacks (47). These ill-fated trials may in fact point to the importance of memory B cells in MS activity because, while inhibiting late state B cells and plasma cells, atacicept selectively spares memory B cells (48).

Bruton's tyrosine kinase (BTK) is a cytoplasmic enzyme important for B cell signaling; inhibition of BTK results in B cell inhibition (49). A phase 2 placebo-controlled trial in RMS patients of varying doses of the oral BTK inhibitor evobrutinib showed fewer CELS at the higher doses compared to placebo (50). Currently, this and several other BTK inhibitors are being studied in MS patients. Early reports suggest moderate efficacy of BTK inhibitors that is not as profound as that seen with anti-CD20 $\mathrm{mAb}$ therapies.

\section{CONCLUSIONS}

In summary, eliminating circulating $\mathrm{CD} 20^{+} \mathrm{B}$ cells leads to a profound reduction in MS clinical and MRI activity in RMS patients. B cells likely contribute to MS pathogenesis in several ways, including their enhancement of $\mathrm{T}$ cell activation and proliferation. B cells are critical for capturing and presenting low concentration antigens, such as myelin proteins to $\mathrm{T}$ cells. 
B cells also likely contribute to MS pathogenesis by direct and indirect production of pro-inflammatory cytokines and chemokines. Elimination of pro-inflammatory CD20 ${ }^{+} \mathrm{T}$ cells may also play a role. The mechanism by which $\mathrm{B}$ cells contribute to MS activity appears to be independent of their role in $A b$ production. Collecting longer-term safety data will be important to determine the safety of using these therapies chronically. Studies to determine exactly how B cell depletion inhibits MS activity will undoubtedly lead to better understanding of MS pathogenesis.

\section{AUTHOR CONTRIBUTIONS}

CR analyzed the clinical trials data and safety information and drafted the manuscript on these topics. AC analyzed the

\section{REFERENCES}

1. Hawker K, O’Connor P, Freedman MS, Calabresi PA, Antel J, Simon J, et al. Rituximab in patients with primary progressive multiple sclerosis: results of a randomized double-blind placebo-controlled multicenter trial. Ann Neurol. (2009) 66:460-71. doi: 10.1002/ana.21867

2. Montalban X, Hauser SL, Kappos L, Arnold DL, Bar-Or A, Comi G, et al. Ocrelizumab versus placebo in primary progressive multiple sclerosis. $N$ Engl J Med. (2017) 376:209-20. doi: 10.1056/NEJMoa1606468

3. Weiner GJ. Rituximab: mechanism of action. Semin Hematol. (2010) 47:11523. doi: $10.1053 /$ j.seminhematol.2010.01.011

4. Quast I, Keller CW, Maurer MA, Giddens JP, Tackenberg B, Wang LX, et al. Sialylation of IgG Fc domain impairs complement-dependent cytotoxicity. $J$ Clin Invest. (2015) 125:4160-70. doi: 10.1172/JCI82695

5. Naismith RT, Piccio L, Lyons JA, Lauber J, Tutlam NT, Parks BJ, et al. Rituximab add-on therapy for breakthrough relapsing multiple sclerosis: a 52-week phase II trial. Neurology. (2010) 74:1860-7. doi: 10.1212/WNL.0b013e3181e24373

6. Hauser SL, Waubant E, Arnold DL, Vollmer T, Antel J, Fox RJ, et al. B-cell depletion with rituximab in relapsing-remitting multiple sclerosis. $N$ Engl $J$ Med. (2008) 358:676-88. doi: 10.1056/NEJMoa0706383

7. Kappos L, Li D, Calabresi PA, O'Connor P, Bar-Or A, Barkhof F, et al. Ocrelizumab in relapsing-remitting multiple sclerosis: a phase 2, randomised, placebo-controlled, multicentre trial. Lancet. (2011) 378:177987. doi: 10.1016/S0140-6736(11)61649-8

8. Sorensen PS, Lisby S, Grove R, Derosier F, Shackelford S, Havrdova E, et al. Safety and efficacy of ofatumumab in relapsingremitting multiple sclerosis: a phase 2 study. Neurology. (2014) 82:573-81. doi: 10.1212/WNL.0000000000000125

9. Fox E, Lovett-Racke AE, Gormley M, Liu Y, Petracca M, Cocozza S, et al. A phase 2 multicenter study of ublituximab, a novel glycoengineered anti-CD20 monoclonal antibody, in patients with relapsing forms of multiple sclerosis. Mult Scler J. (2020). doi: 10.1177/1352458520918375. [Epub ahead of print].

10. Bar-Or A, Calabresi PAJ, Arnlod D, Markowitz C, Shafer S, Kasper LH, et al. Rituximab in relapsing-remitting multiple sclerosis: a 72-week, open-label, phase I trial. Ann Neurol. (2008) 63:395-400. doi: 10.1002/ana.21363

11. Rituximab Prescribing Information. Reference ID: 4663614. (2020). Available online at: https://www.gene.com/download/pdf/rituxan_prescribing.pdf

12. Hauser SL, Bar-Or A, Comi G, Giovannoni G, Hartung HP, Hemmer B, et al. Ocrelizumab versus interferon beta-1a in relapsing multiple sclerosis. $N$ Engl J Med. (2017) 376:221-34. doi: 10.1056/NEJMoa1601277

13. Hauser SL, Bar-Or A, Cohen JA, Comi G, Correale J, Coyle PK, et al. Ofatumumab versus teriflunomide in multiple sclerosis. N Engl J Med. (2020) 383:546-57. doi: 10.1056/NEJMoa1917246

14. Morschhauser F, Marlton P, Vitolo U, Lindén O, Seymour JF, Crump M, et al. Results of a phase I/II study of ocrelizumab, a fully humanized anti-CD20 mechanisms of action data and drafted the manuscript, revised the draft of clinical trials and safety data, and approved the final draft. All authors contributed to the article and approved the submitted version.

\section{ACKNOWLEDGMENTS}

We gratefully acknowledge the generous support of The Leon and Harriet Felman Fund for Human MS Research. AC was supported by the Manny \& Rosalyn Rosenthal-Dr. John L. Trotter MS Center Chair in Neuroimmunology of the BarnesJewish Hospital Foundation. The Phase 2 study of rituximab done at Washington University was supported by the National MS Society USA. We thank Dr. David B. Clifford for helpful discussion on PML in relation to anti-CD20 therapies.

$\mathrm{mAb}$, in patients with relapsed/refractory follicular lymphoma. Ann Oncol. (2010) 21:1870-6. doi: 10.1093/annonc/mdq027

15. Taylor RP, Pawluczkowycz AW, Lindorfer MA, van de Winkel JGJ, Beurskens FJ, Parren PWHI. Binding of submaximal C1q to B cells opsonized with anti-CD20 mabs ofatumumab (OFA) or rituximab (RTX) promotes complement dependent cytotoxicity (CDC), and considerably higher levels of CDC are induced by OFA than by RTX. Blood. (2008) 112:15788. doi: 10.1182/blood.V112.11.1578.1578

16. Le Garff-Tavernier M, Herbi L, De Romeuf C, Nguyen-Khac F, Davi F, Grelier A, et al. Antibody-dependent cellular cytotoxicity of the optimized anti-CD20 monoclonal antibody ublituximab on chronic lymphocytic leukemia cells with the 17p deletion. Leukemia. (2014) 28:230-3. doi: 10.1038/leu.2013.240

17. Bar-Or A, Grove RA, Austin DJ, Tolson JM, Vanmeter SA, Lewis EW, et al. Subcutaneous ofatumumab in patients with relapsing-remitting multiple sclerosis: the MIRROR study. Neurology. (2018) 90:E180514. doi: 10.1212/WNL.0000000000005516

18. De Romeuf C, Dutertre CA, Le Garff-Tavernier M, Fournier N, Gaucher C, Glacet A, et al. Chronic lymphocytic leukaemia cells are efficiently killed by an anti-CD20 monoclonal antibody selected for improved engagement of Fc $\gamma$ RIIIA/CD16. Br J Haematol. (2008) 140:635-43. doi: 10.1111/j.1365-2141.2007.06974.x

19. Caldito NG, Shirani A, Salter A, Stuve O. Adverse event profile differences between rituximab and ocrelizumab: findings from the FDA adverse event reporting database. Mult Scler J. (2020). doi: 10.1177/1352458520949986. [Epub ahead of print]

20. Clifford DB, Gass A, Richert N, Tornatore C, Vermersch P, Hughes $\mathrm{R}$, et al. Cases reported as progressive multifocal leukoencephalopathy in Ocrelizumab-treated patients with multiple sclerosis. Mult Scler J. (2019) 25:509.

21. Sormani MP, De Rossi N, Schiavetti I, Carmisciano L, Cordioli C, Moiola L, et al. Disease modifying therapies and COVID-19 severity in multiple sclerosis. SSRN. (2020). doi: 10.2139/ssrn.3631244

22. Louapre C, Collongues N, Stankoff B, Giannesini C, Papeix C, Bensa C, et al. Clinical characteristics and outcomes in patients with coronavirus disease 2019 and multiple sclerosis. JAMA Neurol. (2020) 77:107988. doi: 10.1001/jamaneurol.2020.2581

23. Salter A, Halper J, Bebo B, Kanellis P, Costello K, Cutter G, et al. COViMS Registry: clinical characterization of SARS-CoV-2 infected multiple sclerosis patients in North America. In: MS Virtual (2020). Abstract \#2128.

24. Simonsen CS, Flemmen HØ, Lauritzen T, Berg-Hansen P, Moen SM, Celius EG. The diagnostic value of IgG index versus oligoclonal bands in cerebrospinal fluid of patients with multiple sclerosis. Mult Scler J Exp Transl Clin. (2020) 6:205521731990129. doi: 10.1177/2055217319901291

25. Villar LM, García-Barragán N, Espiño M, Roldán E, Sádaba M, Gómez-Rial $\mathrm{J}$, et al. Influence of oligoclonal IgM specificity in multiple sclerosis disease course. Mult Scler. (2008) 14:183-7. doi: 10.1177/1352458507082046 
26. Avasarala JR, Cross AH, Trotter JL. Oligoclonal band number as a marker for prognosis in multiple sclerosis. Arch Neurol. (2001) 58:20445. doi: 10.1001/archneur.58.12.2044

27. Piccio L, Naismith RT, Trinkaus K, Klein RS, Parks BJ, Lyons JA, et al. Changes in B- and T-lymphocyte and chemokine levels with rituximab treatment in multiple sclerosis. Arch Neurol. (2010) 67:70714. doi: 10.1001/archneurol.2010.99

28. Barr TA, Shen P, Brown S, Lampropoulou V, Roch T, Lawrie S, et al. B cell depletion therapy ameliorates autoimmune disease through ablation of IL-6producing B cells. J Exp Med. (2012) 209:1001-10. doi: 10.1084/jem.20111675

29. Longbrake EE, Cross AH. Effect of multiple sclerosis disease-modifying therapies on B cells and humoral immunity. JAMA Neurol. (2016) 73:21925. doi: 10.1001/jamaneurol.2015.3977

30. Baker D, Marta M, Pryce G, Giovannoni G, Schmierer K. Memory B cells are major targets for effective immunotherapy in relapsing multiple sclerosis. EBioMedicine. (2017) 16:41-50. doi: 10.1016/j.ebiom.2017.01.042

31. Novi G, Bovis F, Fabbri S, Tazza F, Gazzola P, Maietta I, et al. Tailoring B cell depletion therapy in MS according to memory B cell monitoring. Neurol Neuroimmunol Neuroinflammation. (2020) 7:845. doi: 10.1212/NXI.0000000000000845

32. Duddy M, Niino M, Adatia F, Hebert S, Freedman M, Atkins H, et al. Distinct effector cytokine profiles of memory and naive human B cell subsets and implication in multiple sclerosis. J Immunol. (2007) 178:60929. doi: 10.4049/jimmunol.178.10.6092

33. Cross AH, Stark JL, Lauber J, Ramsbottom MJ, Lyons JA. Rituximab reduces $\mathrm{B}$ cells and $\mathrm{T}$ cells in cerebrospinal fluid of multiple sclerosis patients. $J$ Neuroimmunol. (2006) 180:63-70. doi: 10.1016/j.jneuroim.2006.06.029

34. Cross AH, Klein RS, Piccio L. Rituximab combination therapy in relapsing multiple sclerosis. Ther Adv Neurol Disord. (2012) 5:3119. doi: 10.1177/1756285612461165

35. Alvarez E, Piccio L, Mikesell RJ, Klawiter EC, Parks BJ, Naismith RT, et al. CXCL13 is a biomarker of inflammation in multiple sclerosis, neuromyelitis optica, and other neurological conditions. Mult Scler J. (2013) 19:12048. doi: $10.1177 / 1352458512473362$

36. Krumbholz M, Theil D, Cepok S, Hemmer B, Kivisäkk P, Ransohoff RM, et al. Chemokines in multiple sclerosis: CXCL12 and CXCL13 up-regulation is differentially linked to CNS immune cell recruitment. Brain. (2006) 129:20011. doi: 10.1093/brain/awh680

37. Constant SL. B lymphocytes as antigen-presenting cells for $\mathrm{CD}^{+}{ }^{+} \mathrm{T}$ cell priming in vivo. J Immunol. (1999) 162:5695-703.

38. Pierce SK, Morris JF, Grusby MJ, Kaumaya P, Buskirk A VAN, Srinivasan M, et al. Antigen-presenting function of B lymphocytes. Immunol Rev. (1988) 106:149-80. doi: 10.1111/j.1600-065X.1988. tb00778.x

39. Linsley PS, Clark EA, Ledbetter JA. T-cell antigen CD28 mediates adhesion with $\mathrm{B}$ cells by interacting with activation antigen B7/BB1. Proc Natl Acad Sci USA. (1990) 87:5031-5. doi: 10.1073/pnas.87.13. 5031

40. Stern JNH, Yaari G, Vander Heiden JA, Church G, Donahue WF, Hintzen RQ, et al. B cells populating the multiple sclerosis brain mature in the draining cervical lymph nodes. Sci Transl Med. (2014) 6:248ra107. doi: 10.1126/scitranslmed.30 08879
41. Palanichamy A, Apeltsin L, Kuo TC, Sirota M, Wang S, Pitts SJ, et al. Immunoglobulin class-switched B cells form an active immune axis between CNS and periphery in multiple sclerosis. Sci Transl Med. (2014) 6:248ra106. doi: 10.1126/scitranslmed. 3008930

42. Serafini B, Rosicarelli B, Magliozzi R, Stigliano E, Aloisi F. Detection of ectopic B-cell follicles with germinal centers in the meninges of patients with secondary progressive multiple sclerosis. Brain Pathol. (2004) 14:16474. doi: 10.1111/j.1750-3639.2004.tb00049.x

43. Schuh E, Berer K, Mulazzani M, Feil K, Meinl I, Lahm H, et al. Features of human $\mathrm{CD}^{+} \mathrm{CD}^{+} 0^{+} \mathrm{T}$ cells. J Immunol. (2016) 197:11117. doi: 10.4049/jimmunol.1600089

44. Palanichamy A, Jahn S, Nickles D, Derstine M, Abounasr A, Hauser SL, et al. Rituximab efficiently depletes increased CD20expressing $\mathrm{T}$ cells in multiple sclerosis patients. J Immunol. (2014) 193:580-6. doi: 10.4049/jimmunol.1400118

45. Von Essen MR, Ammitzbøll C, Hansen RH, Petersen ERS, McWilliam O, Marquart HV, et al. Proinflammatory CD20 ${ }^{+} \mathrm{T}$ cells in the pathogenesis of multiple sclerosis. Brain. (2019) 142:120-32. doi: 10.1093/brain/awy301

46. Agius MA, Klodowska-Duda G, Maciejowski M, Potemkowski A, Li J, Patra K, et al. Safety and tolerability of inebilizumab (MEDI-551), an antiCD19 monoclonal antibody, in patients with relapsing forms of multiple sclerosis: Results from a phase 1 randomised, placebo-controlled, escalating intravenous and subcutaneous dose study. Mult Scler J. (2019) 25:23545. doi: $10.1177 / 1352458517740641$

47. Kappos L, Hartung HP, Freedman MS, Boyko A, Radü EW, Mikol DD, et al. ATAMS: A randomised trial of the B-cell-targeting agent atacicept in patients with relapsing multiple sclerosis. Mult Scler. (2011) 17:S40. doi: $10.3325 / \mathrm{cmj} .2019 .60 .87$

48. Hartung HP, Kieseier BC. Atacicept: targeting B cells in multiple sclerosis. Ther Adv Neurol Disord. (2010) 3:205-16. doi: 10.1177/1756285610371146

49. Crofford LJ, Nyhoff LE, Sheehan JH, Kendall PL. The role of Bruton's tyrosine kinase in autoimmunity and implications for therapy. Expert Rev Clin Immunol. (2016) 12:763-73. doi: 10.1586/1744666X.2016.11 52888

50. Montalban X, Arnold DL, Weber MS, Staikov I, Piasecka-Stryczynska K, Willmer J, et al. Placebo-controlled trial of an oral BTK inhibitor in multiple sclerosis. N Engl J Med. (2019) 380:2406-17. doi: 10.1056/NEJMoa1901981

Conflict of Interest: AC has received research grants from EMD Serono and Genentech/Roche, and fees for serving on scientific advisory boards for Biogen, Celgene, EMD Serono, Genentech, Novartis, and Roche, Janssen Pharmaceuticals and Greenwich Biosciences.

The remaining author declares that the research was conducted in the absence of any commercial or financial relationships that could be construed as a potential conflict of interest.

Copyright (c) 2021 Roach and Cross. This is an open-access article distributed under the terms of the Creative Commons Attribution License (CC BY). The use, distribution or reproduction in other forums is permitted, provided the original author(s) and the copyright owner(s) are credited and that the original publication in this journal is cited, in accordance with accepted academic practice. No use, distribution or reproduction is permitted which does not comply with these terms. 